\title{
A Typology of Tasks for Mobile-Assisted Language Learning: Recommendations from a Small-Scale Needs Analysis
}

\author{
Moonyoung Park E Tammy Slater
}

In response to the research priorities of members of TESOL (Teachers of English to Speakers of Other Languages), this study investigated language learners' realworld tasks in mobile-assisted language learning (MALL) to inform the future development of pedagogic tasks for academic English as a second language (ESL) courses. The data included initial semistructured interviews with four ESL teachers and four college ESL students followed by an online task-based needs analysis conducted with 23 ESL teachers and 76 college ESL students at a university in the midwestern United States. Through the interviews and surveys, we identified how teachers and students used mobile devices and how they felt mobile devices could be used in language learning, and we categorized their target tasks in MALL according to the four language skills (reading, listening, speaking, and writing). The study found that ESL learners already use various mobile device functions, but that ESL instructors were less inclined to use these for teaching, suggesting that teachers may need further support and ideas before they can help their learners take advantage of their mobile devices for language learning. Both learners and teachers gave high rankings to tasks for listening and speaking as well as to activities integrated with SMS and the Internet. Based on the identified tasks, we created a MALL task typology to provide an initial authentic and sound resource for the future development of MALL tasks, lesson plans, and curricula.

En réponse aux priorités de recherche des membres de TESOL (enseignement de l'anglais à des apprenants étrangers), cette étude a porté sur les tâches réelles dans le contexte de l'apprentissage mobile des langues pour ensuite éclairer le développement de tâches pédagogiques pour l'anglais académique dans les cours d'anglais langue seconde (ALS). La collecte des données a inclus des entrevues initiales semi-structurées auprès de quatre enseignants d'ALS et quatre étudiants d'ALS à l'université, ainsi qu'une analyse des besoins basée sur les tâches et accomplie en ligne auprès de 23 enseignants d'ALS et 76 étudiants d'ALS dans une université du Midwest des États-Unis. Les entrevues et les enquêtes ont permis d'identifier l'emploi que faisaient les enseignants et les étudiants des appareils mobiles ainsi que leurs perceptions du rôle que pouvaient jouer les appareils dans l'apprentissage d'une langue. Par la suite, nous avons classé leurs tâches cibles selon quatre compétences linguistiques (lecture, écoute, expression orale et rédaction). Les résultats indiquent que les apprenants d'ALS se servent déjà de diverses fonctions des appareils mobiles mais que les enseignants d'ALS étaient moins portés à s'en servir pour l'enseignement, ce qui porte à croire qu'il faudrait peut- 
être leur offrir plus d'appui et d'idées de sorte à ce qu'ils soient en mesure d'aider les apprenants à profiter de leurs appareils mobiles pour apprendre la langue. Tant les apprenants que les enseignants ont attribué beaucoup d'importance aux tâches liées à l'écoute, à l'expression orale, à la messagerie texte et à l'Internet. À partir des tâches identifiées, nous avons créé une typologie des tâches pour l'apprentissage mobile des langues, fournissant ainsi une première ressource authentique et solide pour le développement futur de tâches, de plans de cours et de programmes d'étude dans le domaine.

There is no doubt that the ownership of mobile devices such as smart phones, tablet PCs, and portable MP3 players has become widespread. As a consequence, mobile technologies have quickly made their way into English as a Second Language (ESL) classrooms, offering advantages through flexibility of time, space, and mode of communication, as can be seen by the increasing number of studies on mobile-assisted language learning (MALL). According to recent survey results (TESOL Research Agenda Task Force, 2014), the use of technology in ESL teaching and learning has become one of the biggest research priorities, and exploring the uses that learners are making of mobile-assisted language learning opportunities is one of the first questions being asked.

Various studies have pointed out the challenges and disadvantages of MALL that result from the limitations of mobile technology (e.g., Nah, White, \& Sussex, 2008; Thornton \& Houser, 2003) and the high cost of mobile devices (e.g., Kiernan \& Aizawa, 2004; Stockwell, 2008), yet a decade of MALL implementation has shown that these tools can provide language learners with real-world opportunities to negotiate meaning and to engage with comprehensible input and output by optimizing e-mail, MALL software, short message service (SMS), online discussion boards, and class management systems. However, little research has been conducted regarding the target tasks that language learners themselves feel they need or want to do using the four target language skills (listening, speaking, reading, and writing) in language learning classrooms that incorporate MALL.

Although several theoretical and empirical studies have been carried out on the topic of MALL to demonstrate its effectiveness, greater effort is needed to identify language learners' real-world target tasks and to develop a typology of pedagogic tasks based on an analysis of learners' perceived needs, a process that Long (2005) emphasized as a foundation of Task-Based Language Teaching (TBLT). Moreover, research needs to address whether teachers also feel they are equipped with the skills and understanding of MALL to meet these perceived needs through the construction of classroom tasks. Thus, given the growing interest in the potential of these tools, the authors of this study conducted a task-based needs analysis to investigate tasks that language learners felt they would benefit from. The goal of the analysis was 
to identify real-world language tasks that ESL learners want or feel they need to undertake using mobile devices to help improve their language ability, and whether instructors' views support the idea that MALL can meet these needs. With this purpose in mind, this study adopted semistructured interviews and an online questionnaire to do a needs analysis, and data were collected from ESL learners and instructors in an intensive English program affiliated with a university in the American midwest.

\section{Theoretical Framework}

Since computer-assisted language learning (CALL) was first introduced in the 1960s through the PLATO (Program Logic for Automated Teaching Operations) project, ongoing endeavours have examined the changes and evolution of CALL (Bax, 2003; Garrett, 2009; Warschauer, 2000) and the evolving relationship that has grown between approaches to second language acquisition (SLA) and CALL (Chapelle, 2001, 2009; Doughty, 1987; Garrett, 1991). Warschauer (2000) identified three phases of CALL as "Structural CALL" (which he had previously referred to as Behavioristic, owing to its focus on using CALL for drill and practice activities to achieve accuracy; see Warschauer \& Healey, 1998), "Communicative CALL" (which matched the move to a more communicative language teaching approach and thus involved more communicative exercises, with a fluency objective), and "Integrative CALL" (the current movement, which focuses more on using computers for authentic discourse and adds learner agency into the objectives). Bax (2003) offered a more consolidated analysis of CALL with three phases he labelled "Restricted CALL" (which made limited use of computers and primarily focused on accuracy, involving closed drills and quizzes), "Open CALL" (which highlighted the use of computers for simulations, games, and forms of computer mediated communication [CMC]), and "Integrated CALL" (which blends computers with language skills through the natural use of computers). In describing this latest stage, Bax referred to the concept of "normalization" as occurring when the technology becomes invisible, embedded in everyday practice and hence normalized (Bax, 2000, 2011). Due to cutting-edge mobile technologies and the high quality of Internet connections that today's mobile devices have, the current technological environment indeed enables such normalization of mobile devices into our daily life and facilitates mobile-assisted language learning as a subset of CALL.

The proliferation of mobile devices also allows educators to create authentic tasks that make use of them for learning language. Since the 1980s, TBLT has become one of the most commonly discussed language teaching approaches in the field of instructed second language acquisition, and it has recently had considerable impact on language education policy, curriculum design, materials development, and classroom teaching. Although there have been attempts to categorize MALL activities based on the types of activi- 
ties and relationships (see, for example, Park, 2011), many researchers, syllabus designers, and educators have paid substantial attention to the TBLT approach because of its potential similarities with real-world situations in which learners need to use their knowledge and language abilities. Many studies have been conducted proposing a variety of instructional ideas for using tasks (Lee, 2000; Willis \& Willis, 2007). Doughty and Long (2003), in charting their methodological principles for using CALL, heralded the use of tasks, rather than texts, as the primary unit of analysis.

Norris (2009) defined TBLT as an approach to second or foreign language education that integrates theoretical and empirical foundations for good pedagogy with a focus on tangible learning outcomes in the form of "tasks" that is, what learners are able to do with the language. Researchers (e.g., Ellis, 2003; Long, 1985; Skehan, 1998) have differed to a certain degree in regard to what characterizes a task and how it is applied in the classroom; however, all seem to agree that learners can best acquire the target language by engaging in activities that they will likely encounter in real-world communicative contexts - what can be considered a criterion of authenticity (Chapelle, 2001). According to Norris (2009), within the framework of TBLT, a task-based needs analysis acknowledges that different students may have different language learning needs. Moreover, Bax (2011) claimed that a "needs audit" (p. 12) is a critical step in determining whether the technology under consideration is becoming normalized in the context. We believe, therefore, that a student-focused needs analysis can provide direction for the construction of pedagogical activities for the classroom that use or reflect the technology applications outside the classroom.

As opposed to conventional needs analysis frameworks such as the target situation analysis (Munby, 1981), the present situation analysis (Richterich \& Chancerel, 1980), and the learning centred approach (Hutchinson \& Waters, 1987), which all use linguistic categories (lexical, structural, notional, and/ or functional) as the units of analysis, task-based needs analysis adopts and utilizes "tasks" as the unit of analysis and syllabus design (Long, 2005). Long highlighted two advantages of task-based needs analysis over conventional needs analyses: (a) a task-based needs analysis identifies the target language use in real-world situations, using the dynamic qualities of the target discourse, while conventional needs analyses provide lists of decontextualized structural items; and (b) the results of a task-based needs analysis can readily be used as input for the task-based lesson or course design.

To better exploit the full range of mobile-assisted learning and to pay more attention to language learners, "technology-mediated tasks" (Chapelle, 2001, p. 2) need to be identified and developed to fit closely to learner needs as well as to focus on both meaning and form. To create synergy between TBLT and MALL, a task-based needs analysis must be carried out to identify language learners' real-world mobile technology tasks in order to inform the development of pedagogic tasks, task-based lesson plans, courses, and cur- 
ricula. Moreover, given that it is the instructor who typically assigns tasks in the language classroom, it is important to bring their voices into the needs analysis so that overlapping target tasks can be identified for the purpose of future curriculum and materials development.

\section{Literature Review}

A review of the literature on MALL over the past 20 years indicates that language teachers and researchers have endeavoured to integrate mobile technologies into everyday practices (e.g., Stockwell, 2010), to invent interesting language learning software and programs (e.g., Ogata et al., 2008), and to suggest future directions for MALL (e.g., Kukulska-Hulme \& Shield, 2007). Research has also made its way into more mainstream books on mobile technology use (e.g., Baron, 2008; Prensky, 2010). MALL studies in general can be classified roughly into two types: implementation studies and review studies.

Implementation studies, which will not be reviewed in detail here, have sought to explore how mobile technology benefits and challenges language learners by measuring learners' perceptions or specific language learning gains made through mobile device use. These studies have focused on specific contexts, mobile device use, and language skills. Burston (2013) offered an annotated bibliography of close to 350 implementation studies, stating that these are the most commonly occurring MALL publications, composing roughly $60 \%$ of the total number of references between 1994 and 2012. Related to this, Lin (2014), in a meta-analysis of 59 studies conducted between 2000 and 2012 on the use of computer-mediated communication (CMC) in second language acquisition studies (SLA), found that CMC is a viable alternative to the traditional language classroom if learner proficiency level, interlocutor type, and task type are taken into consideration, suggesting that traditional tasks may need to be modified in some way to accommodate new technology. And the number of MALL implementation studies continues to grow. It is important to note that the language activities and target tasks adopted in these implementation studies were planned and selected by teachers and researchers. In fact, Herrington, Herrington, Mantei, Olney, and Ferry (2009) go so far as to state that the current use of mobile technologies tends to reflect a predominantly teacher-centred paradigm, with educators falling back on "old pedagogies as they come to terms with the capabilities of new technologies" (p. 2). This is reiterated by Kukulska-Hulme and Shield (2008), who commented that MALL is finally beginning to move from a more traditional teacher/learner model to something that can provide learners with opportunities to work collaboratively in problem-solving and meaning negotiation. Burston (2014), however, maintained that the emphasis in MALL continues to reflect a "behaviorist, teacher-centered framework" (p. 346), and that the highly advanced communication features of mobile devices are not being exploited. Godwin-Jones (2011) laments that "it would be a shame to fall into 
only the same use patterns as in the past" (p. 7). Moreover, most teachers and researchers interested in MALL themes are largely unfamiliar with how to build and tailor mobile-based learning materials for their students and participants (Lee \& Lee, 2013).

Although implementation studies have taken up the majority of articles published on MALL (Burston, 2013), review studies (e.g., Bax, 2011; Burston, 2014; Chinnery, 2006; Godwin-Jones, 2011; Kukulska-Hulme \& Shield, 2007; Shudong \& Higgins, 2006) have described and critiqued the approaches taken for MALL implementation, and have also suggested directions for future MALL research and applications. From those studies, findings have shown that despite numerous challenges such as small screen sizes, limited audiovisual quality, limited text message length, virtual keyboarding, limited power, and high costs, the portability and high rate of ownership of mobile devices have provided an impetus for language learners to study or practice with manageable chunks of information in any place on their own time, thereby taking advantage of the convenience of these devices (Chinnery, 2006).

These review studies have emphasized the teacher-based and researchbased nature of MALL; in fact, very few empirical studies have targeted students' needs or abilities with mobile devices. In a guest editorial titled "Mobile learning as a catalyst for change," Kukulska-Hulme (2010) called for educators to have greater understanding of the needs, circumstances, abilities, and previous experiences of learners as they use mobile devices in both formal and informal learning contexts. This call for a "needs audit" was reiterated in Bax (2011), as the first step in a two-step implementation, with the second step being a structured learning plan. This has led to a very small number of empirical studies that explored students' perceptions of MALL (e.g., Bibby, 2011; Kim, Rueckert, Kim, \& Seo, 2013). Findings from these studies suggest that mobile devices can be exploited for language teaching and that in fact there are many students who wish to use-and indeed do use-these devices for study outside of the classroom. The logical next step, therefore, would be to find out what mobile devices students are using for language learning outside of the classroom so that teachers and materials developers can use students' existing abilities to promote language development. To do this, we combine MALL and TBLT to conduct a task-based needs analysis.

\section{Research Questions}

The purpose of this study was to identify MALL-based target tasks for college-level ESL learners and to classify the identified tasks into target task types. This study also aimed to investigate the usability of mobile devices for language learning by college ESL learners. These goals address some of the key priorities for research identified in the 2014 TESOL survey (TESOL Research Agenda Task Force, 2014). Keeping these purposes in mind, the following research questions were developed: 
1. What are the ESL teachers' and learners' patterns of use regarding mobile devices, including frequency and preferences among mobile device functions, and their experiences of mobile learning?

2. What are the target language tasks according to the four skills (reading, listening, speaking, and writing) that college ESL learners need/want to perform using mobile-assisted language learning and teaching?

In order to develop closed-response questions about the target tasks in the four language skills, semistructured interviews were first conducted with ESL teachers and learners. Based on the findings from the interviews and previous studies on task-based needs, an online questionnaire was developed and administered.

\section{Methods}

As our research focuses on conducting a task-based needs analysis and developing a typology, we follow the first two of the six steps for developing a TBLT program provided by Long and Norris (2000):

1. Conduct a task-based needs analysis to identify target tasks.

2. Classify target tasks into target task types.

3. Derive pedagogic tasks.

4. Sequence pedagogic tasks.

5. Implement syllabus with appropriate methodology and pedagogy.

6. Assess student achievement using task-based, criterion-referenced performance tests.

According to Long (2005), target tasks are the outcomes of task-based needs analysis and consist of activities done in everyday life (e.g., purchasing a bus ticket, asking for directions to a building). These target tasks can be classified into certain task types that are more abstract and superordinate than the target tasks (e.g., requesting information). Reasons for considering this superordinate-subordinate relationship include not having enough time in language classrooms to cover all the identified target tasks in the subordinate group, and the usefulness of a typology as a means to cope with the diverse needs of heterogeneous groups of learners (Long, 1985).

With all six steps in mind, the current study aimed to identify target tasks (Step 1) from both the learners' and instructors' perspectives, and to then classify these into a typology (Step 2). Specific target tasks of college ESL learners were determined through interviews and questionnaires, and these tasks were then classified under superordinate target task types.

\section{Procedure and Participants}

The first stage of the research was qualitative and involved semistructured interviews with four teachers and four ESL students. The teachers were graduate teaching assistants in the university's English department. Their ages ranged from 24 to 34 with 1-5 years of EFL/ESL teaching experience at the 
college level; three were females from Korea and one was a male from Turkey. The four student participants were all male Chinese native speakers with ages ranging from 20 to 22 and with 9-11 years of English learning experience.

These interviews elicited data in four major categories, covering participants' (a) bio-data, including age, length of time studying English, country of origin, and program of study; (b) current use of mobile devices, including frequency and purpose of use as well as probing whether the use of mobile devices would be valuable in their language learning; (c) desired target language tasks for MALL, such as the types of tasks wanted; and (d) perceptions of the potentials and challenges of MALL. These interviews were conducted so that viewpoints on participants' mobile device usage, their desired target tasks in MALL, and perceived potentials and challenges in MALL could emerge freely and inform the questionnaire. The interviews lasted between 30 and 50 minutes and were recorded with a digital voice recorder with the consent of the interviewees. An open-coding analysis of these interviews focused on uncovering ESL learners' and teachers' use of and attitudes toward their mobile devices, their perceived challenges and potentials, and their desired target tasks in MALL. Open-ended responses on both students' and teachers' perceptions and their desired target tasks in MALL were then categorized under two main themes: (a) participants' current mobile device use and their actual practice with MALL and (b) their desired target tasks in MALL.

Based on the information gathered in these interviews as well as a preliminary literature review of MALL and task-based needs analysis (e.g., van Ek, 1975; Watanabe, 2006; Yoshida \& Naganuma, 2003), an online questionnaire was developed and piloted to collect quantitative data, and revisions were made before the final questionnaire was released for use through SurveyMonkey. The final questionnaire respondents included 23 ESL teachers and 76 ESL students in the same university. The teachers' ages ranged from 25 to 42 with 1-17 years of teaching experience. The students' ages ranged from 18 to 30 with 2-20 years of English learning experience; their fields of study included aerospace, accounting, business, computer science, engineering, and food science. Two thirds of the online survey participants were native Chinese speakers $(n=51)$, with the remainder native Arabic, Korean, Spanish, and Thai speakers. Forty-seven students (62\%) were male and 29 (38\%) were female. All students could be categorized in one of two groups: they had either been formally accepted as undergraduate students and were taking language courses to meet the requirements of the university (i.e., they had been admitted, but they had not passed the basic English placement tests in speaking, listening, reading, and writing), or they were taking English courses in the university's Intensive English Orientation Program, a program that prepares students who did not pass the TOEFL (Test of English as a Foreign Language) for academic study in English.

The beginning of this online questionnaire sought open-ended responses (Section 1) to obtain participants' perceptions regarding the overall target task needs for the use of English in mobile-assisted language learning and 
teaching. The question asked participants to "list the five most important and desirable tasks in each of the language skills that ESL students should be able to do in English with mobile devices" and provided space to do so under the headings of Listening, Reading, Speaking, and Writing. The answers to these questions offered fuller detail for the quantitative data by providing information about participants' preferences based on the number of like responses. As with the interviews, Section 2 targeted mobile device use. This section included two yes/no questions that guided participants to respond to appropriate questions, three open-ended questions targeting how mobile devices have been used or could be used in participants' experiences (including the challenges), and seven closed-style questions. Of the seven closed questions, three utilized a 4-point Likert scale moving from negative to positive (very uncertain or strongly disagree, to very confident or strongly agree), two involved checking all that apply (types of mobile devices, types of functions), one asked participants to rank functions from least to most important, and one asked participants to identify frequency of use (five categories, from never to more than 10 times a day). Section 3 involved all closed-response items and utilized a four-point Likert scale (e.g., 1: Not at all, 2: Not so much, 3: Somewhat, and 4: A lot) so as to avoid neutral responses. These closed-response items were grouped into three skill-defined sections, with reading first, followed by listening/speaking, and finally writing. The sections were headed "students will be able to" and listed all tasks identified in the interviews as well as input from the literature on MALL. The final section elicited participant's background information.

ESL teachers and ESL students at the university were invited via e-mail and face-to-face meetings to participate voluntarily in the online questionnaire, which was administered using SurveyMonkey. All participants remained anonymous. The responses were collected over a two-week period. Descriptive statistics were used to show how the teachers and students perceived the degree of importance of target tasks based on the four language skills. The reliability of measurement was calculated using Cronbach's alpha to indicate the degree of internal consistency for each subsection of the survey for both students' responses and teachers' responses (see Table 1). The reliability for the subcategories ranged from $\alpha=0.90$ to 0.97 for students and from $\alpha=0.88$ to 0.96 for the teachers, which suggests high internal consistency.

Table 1

Subsection Reliabilities

\begin{tabular}{lccc}
\hline Variable & $k$ & Students $(N=76)$ & Teachers $(N=23)$ \\
\hline Reading & 9 & 0.90 & 0.88 \\
Listening and speaking & 20 & 0.95 & 0.91 \\
Writing & 11 & 0.94 & 0.91 \\
Overall & 40 & 0.97 & 0.96 \\
\hline
\end{tabular}

Note. $(k)=$ Number of question items. 


\section{Results}

The results are based on the initial interviews and the online questionnaire. The findings were classified into two thematic areas regarding participants' current mobile device use or their actual practices with MALL, and their desired target tasks in MALL. These correspond to Research Question 1 (What are the ESL learners' patterns of use regarding mobile devices, including frequency and preferences among mobile device functions, and their experiences of mobile learning?) and Research Question 2 (What are the target language tasks according to the four skills-reading, listening, speaking, and writing - that college ESL learners need/want to perform using mobileassisted language learning and teaching?). Note that not all participants responded to all questions; some skipped over particular items. Moreover, some questions invited more than a single response.

\section{RQ1: Current Mobile Device Use and Actual Practice of MALL}

An understanding of the participants' use of mobile devices was explored by examining their previous MALL experience, their frequency of mobile device use, and their prior experience of MALL. All of the responding ESL teachers and students reported that they owned a mobile device, with some saying they owned more than one. Table 2 indicates that students appeared to have better mobile access to the Internet than did teachers; in fact, only one of four teachers in general confessed to using a smartphone for more than traditional communication purposes. Although $62 \%$ of the students own an Internetenabled phone, a closer look into the collected online survey data indicated that students who had no Internet-connected mobile phone still possessed a tablet PC, iPad, or iPod Touch that enabled them to have occasional access to the Internet. Even though types and models varied, the widespread ownership of Internet-accessing mobile devices, especially among students, reflects strong potential for future classroom implementation of MALL.

Table 2

Ownership of Mobile Devices

\begin{tabular}{lcccr}
\hline Mobile devices & \multicolumn{2}{c}{ Teachers $(n=20)$} & \multicolumn{2}{c}{ Students $(n=58)$} \\
\hline Mobile phone with Internet & $26 \%$ & 6 & $62 \%$ & 47 \\
Mobile phone without Internet & $48 \%$ & 11 & $10 \%$ & 8 \\
Tablet PC & $0 \%$ & & $13 \%$ & 10 \\
iPad & $9 \%$ & 2 & $8 \%$ & 6 \\
iPod Classic & $4 \%$ & 1 & $3 \%$ & 2 \\
iPod Touch & $13 \%$ & 3 & $4 \%$ & 3 \\
\hline
\end{tabular}

Table 3 summarizes the survey results regarding the frequency of usage of various mobile device features. The numbers in Table 3 denote how often sur- 
vey participants used a certain mobile device function per day or per week. Considering both daily and weekly usage, there appeared to be agreement among the participants that Calendar, Voice Call, and Text Message are the three most frequently used mobile device functions. Interestingly, students utilized all of the functions fairly often. In contrast, there are numerous functions (e.g., Dictionary, Game, Voice Recorder) that were never utilized by $70 \%$ or more of the teachers.

Students' daily use of the mobile device functions is especially worthy of notice as it illustrates actual conditions of usage. The three most frequently used functions are Chat in Text, Text Message, and Dictionary, followed by Web Browser and Voice Call. This finding may suggest that students are utilizing a mobile device as an interactive text-based communication tool as well as a reference tool to search vocabulary and online information that, like the ownership results, reflects strong potential for future implementation of MALL.

Table 3

Frequency of Mobile Device Features Usage

\begin{tabular}{|c|c|c|c|c|c|c|}
\hline \multirow[b]{2}{*}{ Functions } & \multicolumn{3}{|c|}{ Students } & \multicolumn{3}{|c|}{ Teachers } \\
\hline & $\begin{array}{l}\text { Several } \\
\text { times per } \\
\text { day }\end{array}$ & $\begin{array}{l}\text { Several } \\
\text { times per } \\
\text { week }\end{array}$ & Never & $\begin{array}{c}\text { Several } \\
\text { times per } \\
\text { day }\end{array}$ & $\begin{array}{l}\text { Several } \\
\text { times per } \\
\text { week }\end{array}$ & Never \\
\hline Game & $40 \%(23)$ & $29 \%(17)$ & $31 \%(18)$ & $15 \%(3)$ & $15 \%(3)$ & $70 \%(14)$ \\
\hline Calendar & $54 \%(31)$ & $39 \%(22)$ & $7 \%(4)$ & $30 \%(6)$ & $50 \%(10)$ & $20 \%(4)$ \\
\hline Voice call & $55 \%(32)$ & $30 \%(17)$ & $15 \%(8)$ & $30 \%(6)$ & $50 \%(10)$ & $20 \%(4)$ \\
\hline Dictionary & $70 \%(40)$ & $11 \%(6)$ & $19 \%(11)$ & $0 \%(0)$ & $25 \%(5)$ & $75 \%(15)$ \\
\hline Chat in text & $72 \%(42)$ & $14 \%(8)$ & $14 \%(8)$ & $25 \%(5)$ & $30 \%(6)$ & $45 \%(9)$ \\
\hline Video player & $36 \%(20)$ & $36 \%(20)$ & $28 \%(15)$ & $10 \%(2)$ & $35 \%(7)$ & $55 \%(11)$ \\
\hline Music player & $46 \%(26)$ & $32 \%(8)$ & $22 \%(12)$ & $15 \%(3)$ & $35 \%(7)$ & $50 \%(10)$ \\
\hline Camera & $45 \%(26)$ & $42 \%(25)$ & $12 \%(7)$ & $15 \%(3)$ & $60 \%(12)$ & $25 \%(5)$ \\
\hline Voice recorder & $23 \%(13)$ & $33 \%(19)$ & $44 \%(25)$ & $5 \%(1)$ & $35 \%(7)$ & $60 \%(12)$ \\
\hline $\begin{array}{l}\text { Video } \\
\text { recorder }\end{array}$ & $20 \%(11)$ & $43 \%(24)$ & $37 \%(21)$ & $5 \%(1)$ & $25 \%(5)$ & $70 \%(14)$ \\
\hline E-mail & $44 \%(25)$ & $30 \%(17)$ & $26 \%(15)$ & $40 \%(8)$ & $10 \%(2)$ & $50 \%(10)$ \\
\hline Text message & $70 \%(41)$ & $15 \%(9)$ & $15 \%(9)$ & $30 \%(6)$ & $45 \%(9)$ & $25 \%(5)$ \\
\hline Web browser & $56 \%(32)$ & $14 \%(8)$ & $3-\%(17)$ & $25 \%(5)$ & $20 \%(4)$ & $55 \%(11)$ \\
\hline "To do" list & $41 \%(23)$ & $36 \%(20)$ & $23 \%(13)$ & $26 \%(5)$ & $26 \%(5)$ & $48 \%(9)$ \\
\hline
\end{tabular}

In order to understand the practice of MALL, closed- and open-ended questions were used to solicit participants' experience. The findings suggested that there is a discrepancy between the teachers and the students regarding their MALL experience. Only 3 of $20(15 \%)$ teachers had experienced MALL in their teaching and learning contexts, compared to 35 of 58 $(60 \%)$ students. The students reported on a variety of MALL activities, among which Use Dictionary and Watch Podcasts were the two most popular. Writing 
activities in MALL were the least practiced among the four language skills, according to the open-ended responses (see Table 4). Given that both ESL teachers and students had pointed out challenges such as the small screen size, the inconvenient keypads, the high cost for online service and devices, and limited battery life, this finding may be the result of technological limitations in mobile technology as much as pedagogical issues in the implementation of writing activities in MALL.

Table 4

MALL Activities Participants Experienced

\begin{tabular}{llc}
\hline Participants & MALL activities & $\#$ \\
\hline Teachers & Listen to podcasts (LS) & 1 \\
(R:2, LS: 1) & Read RSS feeds to read news (R) & 1 \\
& Use dictionary (R) & 1 \\
Students & Chat with friends (W) & 1 \\
(R: 26, LS: 22, W:2) & Use web browser to translate English phrases (R) & 3 \\
& Practice listening (LS) & 3 \\
& Use dictionary (R) & 22 \\
& Watch news (LS) & 1 \\
& Write a short paper (W) & 1 \\
& Web surfing to find information (R) & 1 \\
& Watch podcasts (LS) & 21 \\
\hline
\end{tabular}

Note. $(\mathrm{R})$ = Reading; (LS) = Listening/Speaking; $(\mathrm{W})=$ Writing.

In general, it appears that teachers were not as familiar with using mobile devices for teaching ( $85 \%$ had never used them in teaching), but they could see their potential. Although they were somewhat skeptical about trying them because of the technological limitations and the pedagogical challenges in class-wide facilitation of MALL, they were $89 \%$ in favor of using mobile devices in teaching. In contrast to this, the students had already been much more involved in using mobile devices to help them with their language development ( $60 \%$ had used them in this way), yet they were much less enthusiastic about bringing these into the classroom context (59\% expressed enthusiasm).

\section{RQ\#2: Target Task Needs in MALL}

The next four tables summarize the open-ended responses (Table 5) and the ranking of participants' desired target tasks in MALL from the closed response questions according to the four language skills: reading (Table 6), listening and speaking (Table 7), and writing (Table 8). Each of the numbers in Table 5 represents the number of mentions made in the open-ended questions. There are consistent patterns throughout the four language skills. Overall, with regard to the perceptions of which tasks students need across the four language skills, the results of this study suggest that both teachers and students had 
similar ideas. In terms of target tasks for reading skills, reading hypertext (e.g., news, novels) was commonly acknowledged as the most desired target task by the two groups, followed by consulting vocabulary resources.

The students appeared to use various sources for listening practice. Among the desired target task responses, listening to music was the most preferred, followed by watching drama and video. Although not mentioned by the students, teachers felt that watching (or listening to) online lectures was the most necessary listening task. For speaking skills, both teachers and students suggested that formal and casual phone conversations were the most needed. Interestingly, the teachers' desired tasks included more diverse uses of technology, such as video chatting, voice recording, voice memo, and voice search -functions most teachers claimed they had never before experienced.

Although they differed slightly in their ranking of writing tasks, both teachers and students emphasized writing in short message service format (SMS), course-related papers, and taking notes as the three most necessary writing tasks, followed by sending e-mails. Additionally, teachers added posting on social networking sites, online text chatting, and filling out official forms as necessary target tasks.

Table 5

Open-ended Responses on Desired Target Tasks in MALL

\begin{tabular}{|c|c|c|}
\hline & Teachers & Students \\
\hline READING & $\begin{array}{l}\text { Read text on/offline (19) } \\
\text { Look up vocabulary (12) } \\
\text { Browse websites (4) } \\
\text { Read e-mails (2) } \\
\text { Read Internet poll (1) }\end{array}$ & $\begin{array}{l}\text { Read news, articles, novel (48) } \\
\text { Look up vocabulary (38) } \\
\text { Read SMS / e-mail (12) } \\
\text { Practice English grammar (4) }\end{array}$ \\
\hline LISTENING & $\begin{array}{l}\text { Watch online lectures (10) } \\
\text { Watch news (9) } \\
\text { Listen to music (8) } \\
\text { Watch podcasts (8) } \\
\text { Watch YouTube (6) } \\
\text { Listen to pronunciation (3) } \\
\text { Listen to voice messages (3) }\end{array}$ & $\begin{array}{l}\text { Listen to music (27) } \\
\text { Watch drama / video (24) } \\
\text { Listen to English speakers on the phone (23) } \\
\text { Watch news (18) } \\
\text { Listen to radio / Podcasts (10) } \\
\text { Watch class lectures (6) }\end{array}$ \\
\hline SPEAKING & $\begin{array}{l}\text { Formal phone call (20) } \\
\text { Casual phone call }(8) \\
\text { Video chatting / CMC (7) } \\
\text { Record voicemails/notes }(6) \\
\text { Voice search }(5)\end{array}$ & $\begin{array}{l}\text { Make casual phone calls / chatting (56) } \\
\text { Make formal phone calls (e.g., making } \\
\text { reservations, ordering food, calling cus- } \\
\text { tomer service, advisors, professors) (35) } \\
\text { Speak over the phone concerning school } \\
\text { work (24) }\end{array}$ \\
\hline WRITING & $\begin{array}{l}\text { Write SMS (11) } \\
\text { Write academic papers (11) } \\
\text { Take notes (9) } \\
\text { Write e-mails (8) } \\
\text { Online chatting (4) } \\
\text { Post on social networking sites (4) } \\
\text { Fill official forms (2) }\end{array}$ & $\begin{array}{l}\text { Take notes (22) } \\
\text { Write essays or reports with online sources } \\
\quad(19) \\
\text { Write SMS (18) } \\
\text { Write e-mails (13) }\end{array}$ \\
\hline
\end{tabular}


Participants were asked to rank their desired target tasks in the four language skills. To analyze the distribution of the responses, rank order is presented in Tables 6 through 8 based on the percentage of survey participants who ranked particular tasks in the same way. A discrepancy was noted between the students and the teachers in their preference for target tasks across the four language skills. Students consistently ranked writing tasks as the most desired target tasks, followed by listening/speaking tasks and reading tasks. On the contrary, teachers ranked listening/speaking tasks as the most favoured target tasks, but no consistency was found beyond that. This could be a result of the teachers' experience using mobile devices primarily for phone calls. Details of the participants' target task preference according to the four language skills are provided below.

Table 6

Closed Responses on Target Task Need in MALL: Reading Skills

\begin{tabular}{|c|c|c|c|c|c|}
\hline & & \multicolumn{2}{|c|}{ Students $(n=54)$} & \multicolumn{2}{|c|}{ Teachers $(n=20)$} \\
\hline & & $\%$ & $\begin{array}{l}\text { Rank (\# of } \\
\text { responses) }\end{array}$ & $\%$ & $\begin{array}{l}\text { Rank (\# of } \\
\text { responses) }\end{array}$ \\
\hline $\mathrm{R} 1$ & $\begin{array}{l}\text { Receive text from textbook via SMS/ } \\
\text { Internet and read it }\end{array}$ & 43 & $2(33)$ & 65 & $9(38)$ \\
\hline $\mathrm{R} 2$ & $\begin{array}{l}\text { Receive vocabulary in textbook via } \\
\text { SMS and review it }\end{array}$ & 42 & $4(35)$ & 90 & $2(11)$ \\
\hline R3 & $\begin{array}{l}\text { Understand new grammar in the text- } \\
\text { book via SMS }\end{array}$ & 45 & $1(32)$ & 75 & $6(33)$ \\
\hline $\mathrm{R} 4$ & $\begin{array}{l}\text { Answer the quiz of the course text- } \\
\text { book via SMS }\end{array}$ & 43 & $2(34)$ & 75 & $6(34)$ \\
\hline R5 & $\begin{array}{l}\text { Understand a text equivalent to the } \\
\text { level of the textbook }\end{array}$ & 42 & $4(36)$ & 75 & $6(35)$ \\
\hline $\mathrm{R} 6$ & $\begin{array}{l}\text { Understand the main idea of essays } \\
\text { or novels in English }\end{array}$ & 41 & $6(37)$ & 85 & $5(21)$ \\
\hline $\mathrm{R} 7$ & $\begin{array}{l}\text { Read an article from newspapers and } \\
\text { magazines in English }\end{array}$ & 41 & $6(38)$ & 90 & $2(12)$ \\
\hline $\mathrm{R} 8$ & $\begin{array}{l}\text { Read class announcements, feed- } \\
\text { back, and homework via SMS }\end{array}$ & 41 & $6(39)$ & 100 & $1(1)$ \\
\hline $\mathrm{R} 9$ & Read the course description & 38 & $9(40)$ & 90 & $2(13)$ \\
\hline
\end{tabular}

Note. The numbers in parentheses indicate the number of times participants chose the task.

Reading. Although students rated reading tasks as the least desired among the 40 target task items across the four language skills, they consistently ranked course-related reading tasks (e.g., R1, R3, and R4 in Table 6) as highly necessary. Compared to students, teachers considered reading tasks as more necessary and ranked several tasks highly, including R2, R7, R8, and R9. Teachers highlighted the reading of class announcements, feedback, and homework as the most essential tasks across the 40 target task items. 
Table 7

Closed Responses on Target Task Need in MALL:

Listening and Speaking Skills

\begin{tabular}{|c|c|c|c|c|c|}
\hline & & \multicolumn{2}{|c|}{ Students $(n=52)$} & \multicolumn{2}{|c|}{ Teachers $(n=20)$} \\
\hline & & $\%$ & $\begin{array}{l}\text { Rank (\# of } \\
\text { responses) }\end{array}$ & $\%$ & $\begin{array}{l}\text { Rank (\# of } \\
\text { responses) }\end{array}$ \\
\hline LS1 & $\begin{array}{l}\text { Engage in informal daily conver- } \\
\text { sations with friends }\end{array}$ & 72 & $11(21)$ & 100 & $1(2)$ \\
\hline LS2 & $\begin{array}{l}\text { Ask teachers for favours on the } \\
\text { phone }\end{array}$ & 78 & $2(10)$ & 32 & $20(40)$ \\
\hline LS3 & $\begin{array}{l}\text { Listen to language podcasts in } \\
\text { English }\end{array}$ & 74 & $3(13)$ & 95 & $2(3)$ \\
\hline LS4 & $\begin{array}{l}\text { Listen to teacher's feedback on } \\
\text { your submitted assignments }\end{array}$ & 68 & $16(26)$ & 85 & $12(22)$ \\
\hline LS5 & $\begin{array}{l}\text { Practice listening comprehension } \\
\text { skills in ESL website }\end{array}$ & 64 & $20(30)$ & 95 & $2(4)$ \\
\hline LS6 & $\begin{array}{l}\text { Voice-record yourself using target } \\
\text { language }\end{array}$ & 70 & $13(23)$ & 90 & $8(14)$ \\
\hline LS7 & $\begin{array}{l}\text { Video-record yourself using target } \\
\text { language }\end{array}$ & 79 & $1(8)$ & 85 & $12(23)$ \\
\hline LS8 & $\begin{array}{l}\text { Introduce your home country cul- } \\
\text { ture in English }\end{array}$ & 70 & $14(24)$ & 90 & $8(15)$ \\
\hline LS9 & $\begin{array}{l}\text { Exchange opinions with your } \\
\text { classmates on classwork }\end{array}$ & 70 & $15(25)$ & 95 & $2(5)$ \\
\hline LS10 & $\begin{array}{l}\text { Exchange opinions on social } \\
\text { problems with one's friend }\end{array}$ & 74 & $4(14)$ & 95 & $2(6)$ \\
\hline LS11 & $\begin{array}{l}\text { Understand the main ideas of the } \\
\text { English pop songs }\end{array}$ & 73 & $6(16)$ & 90 & $8(16)$ \\
\hline LS12 & Sing one's favorite English song & 73 & $8(17)$ & 85 & $12(24)$ \\
\hline LS13 & $\begin{array}{l}\text { Understand the main idea of TV } \\
\text { shows/ movies in English }\end{array}$ & 72 & $12(22)$ & 70 & $18(37)$ \\
\hline LS14 & $\begin{array}{l}\text { Tell the summary of TV shows/ } \\
\text { movies to a friend in English }\end{array}$ & 66 & $18(28)$ & 85 & $12(25)$ \\
\hline LS15 & $\begin{array}{l}\text { Exchange one's feelings and } \\
\text { opinions about TV/movies }\end{array}$ & 73 & $9(18)$ & 90 & $8(17)$ \\
\hline LS16 & $\begin{array}{l}\text { Deliver a speech or give a pre- } \\
\text { sentation in English }\end{array}$ & 73 & 7 (19) & 65 & 19 (39) \\
\hline LS17 & $\begin{array}{l}\text { Speak English with attention to } \\
\text { pronunciation, intonation }\end{array}$ & 74 & $5(15)$ & 85 & $12(26)$ \\
\hline LS18 & $\begin{array}{l}\text { Answer the questions in the lis- } \\
\text { tening practice assignments }\end{array}$ & 68 & $17(27)$ & 80 & $17(31)$ \\
\hline LS19 & $\begin{array}{l}\text { Listen to voice messages and } \\
\text { understand them }\end{array}$ & 65 & $19(29)$ & 95 & $2(7)$ \\
\hline LS20 & $\begin{array}{l}\text { Make a reservation for transpor- } \\
\text { tation, restaurant, hotel, etc. }\end{array}$ & 73 & $10(20)$ & 95 & $2(8)$ \\
\hline
\end{tabular}

Note. The numbers in parentheses indicate the number of times participants chose the task. 
Listening and speaking. Overall, ESL students expressed moderate needs for listening and speaking tasks. Among the 20 listening and speaking tasks listed, Video-record yourself using target language (LS7) and Ask teachers for favuors on the phone (LS2) were perceived as the two most necessary, ranked within the top 10 of 40 overall tasks for ESL students. In addition to the use of video-recording and voice phone conversation, students hoped to interact with a teacher or friends formally and informally, utilizing diverse smart phone functions including music players, podcasts, pronunciation practice apps, and voice recorders.

In contrast, teachers ranked seven listening and speaking tasks in the top 10 most necessary tasks. They regarded Engage in informal daily conversations with friends (LS1) as the most necessary target task followed by various listening practices (LS3, LS5, LS19), exchanging opinions (LS9, LS10), and Make a reservation (LS20). Interestingly, when each group's most desired tasks in listening and speaking skills were compared, it could be seen that teachers emphasized listening skills as well as speaking skills, while students expressed more need for speaking skills alone.

Table 8

Closed Responses on Target Task Need in MALL: Writing Skills

\begin{tabular}{|c|c|c|c|c|c|}
\hline & & \multicolumn{2}{|c|}{ Students $(N=53)$} & \multicolumn{2}{|c|}{ Teachers $(N=20)$} \\
\hline & & $\%$ & $\begin{array}{l}\text { Rank (\# of } \\
\text { responses) }\end{array}$ & $\%$ & $\begin{array}{l}\text { Rank (\# of } \\
\text { responses) }\end{array}$ \\
\hline$\overline{\mathrm{W} 1}$ & Keep a diary in English & 62 & $11(31)$ & 85 & $6(27)$ \\
\hline W2 & $\begin{array}{l}\text { Take a note of a lecture or a pre- } \\
\text { sentation }\end{array}$ & 79 & $8(9)$ & 75 & $11(36)$ \\
\hline W3 & $\begin{array}{l}\text { Communicate with friends by } \\
\text { synchronous online chatting }\end{array}$ & 83 & $5(4)$ & 85 & $7(28)$ \\
\hline W4 & $\begin{array}{l}\text { Communicate with friends by } \\
\text { writing emails }\end{array}$ & 85 & $2(1)$ & 95 & $1(9)$ \\
\hline W5 & $\begin{array}{l}\text { Communicate with friends by } \\
\text { sending SMS }\end{array}$ & 85 & $1(2)$ & 90 & $3(18)$ \\
\hline W6 & $\begin{array}{l}\text { Communicate with professors or } \\
\text { staffs by writing e-mail }\end{array}$ & 81 & $6(6)$ & 95 & $2(10)$ \\
\hline W7 & $\begin{array}{l}\text { Write a summary of a story, } \\
\text { novel, or other people's opinions }\end{array}$ & 81 & $7(7)$ & 85 & $8(29)$ \\
\hline W8 & $\begin{array}{l}\text { Write class feedback and post it } \\
\text { to a course website }\end{array}$ & 75 & $9(11)$ & 90 & $4(19)$ \\
\hline W9 & $\begin{array}{l}\text { Post on social networking sites } \\
\text { (e.g. Facebook, Twitter) }\end{array}$ & 83 & $4(5)$ & 90 & $5(20)$ \\
\hline W10 & $\begin{array}{l}\text { Write composition homework and } \\
\text { post to a course website }\end{array}$ & 75 & $10(12)$ & 80 & $10(32)$ \\
\hline W11 & $\begin{array}{l}\text { Post grammar/vocabulary home- } \\
\text { work on a course website }\end{array}$ & 84 & $3(3)$ & 85 & $9(30)$ \\
\hline
\end{tabular}

Note. The numbers in parentheses indicate the number of times participants chose the task. 
Writing. Students regarded writing tasks as the most necessary, with eight of these writing tasks ranked in their top 10. This emphasized their need to communicate with professors or friends through diverse media such as SMS, e-mail, learning management systems (LMS) such as their course website, social networking sites (SNS), and online chatting (W3, W4, W5, W6, W9, W11). In contrast to the students, teachers ranked only two writing tasks within the top 10-writing informal and formal e-mails (W4, W6) - but ranked roughly half of the writing tasks in the lower 20 out of 40 overall. However, considering the relatively high percentage of teachers' responses, ranging from $75 \%$ to $95 \%$ in favour of target tasks for writing, it seems as though both teachers and students felt writing tasks were valuable.

\section{Discussion}

Although researchers such as Ellis (2003), Long (1985), and Skehan (1998) have differed in regards to what characterizes a classroom task, all have agreed that learners are likely to acquire the target language by engaging in practices that mirror real-life contexts. As a review of the literature has suggested, there have been and continue to be vast numbers of implementation studies exploring the use of mobile devices in language learning, but few studies have looked at what language learners and their teachers are currently doing with their mobile devices. Such a needs analysis is critical if we are attempting to create classroom tasks that have high levels of authenticity and that seek to move beyond what Burston (2014, p. 352) claims reflects a "behaviorist, teacher-centered, transmission model" to a position where the mobile devices are used "in conformity with their intrinsic functionality ... as powerful multimedia communication devices, to build and maintain language learning communities." Along these lines, we are suggesting that it is critical to include the voices of both the learners and their instructors so as to learn from the overlapping target tasks.

This study thus first attempted to establish what types of mobile devices the ESL teachers and students have been using and what their experiences have been with MALL. Our findings showed that while all participants owned at least one mobile device (and many more than one), about $60 \%$ of the ESL students reported already using these in a language-learning capacity, compared to $15 \%$ of ESL teachers who used mobile devices in their instruction, suggesting that teachers appear to be lagging behind in their mobile device use in the context of language education. Although these findings support previous findings regarding the widespread ownership of mobile devices, we could not identify research that has been carried out to explicitly examine whether and how ESL teachers and learners were using their devices for language-learning (or teaching) purposes, beyond the implementation studies previously reviewed (e.g., Stockwell, 2008). What our findings also support, as Prensky (2010) suggested, is that the varied use of mobile 
technology is commonplace outside of the language classroom, at least from the students' perspective, and that many of these tasks were construed by the participants as language-learning tasks.

It must be kept in mind that the majority of our student participants were Chinese males. Zhang, Song, and Huang (2014) reported that mobile devices have become what Bax (2011) calls normalized for Chinese university students, not only for such uses as communication and entertainment, but also for language learning, to "improve their English reading and vocabulary building by reading English news on the phone and to enhance their listening skills by watching movie clips and listening to digital media in English while they are on the go" (p. 47). Thus the self-reporting of use in language learning may be different than what would be found in a needs analysis with fewer Chinese students. Moreover, these students self-reported their years of study in English, thus suggesting a range of proficiency. However, as all were engaged in English for academic purposes at the university, they could all be considered intermediate-level learners who were perhaps more motivated to study than other language learners and were therefore using their mobile devices for language learning more than a random sample would show. Moreover, our study (like many of the implementation studies) did not explore gender differences in mobile device use or preferences, an area that would be of high interest for future needs assessments.

What the current study also uncovered was that students felt quite strongly about certain tasks they should be able to perform using mobile devices, a point that is addressed in our second research question. Following Long (1985) and Long and Norris (2000) on the need for task-based needs analysis, our study thus identified target tasks by comparing learner- and teacher-perceived needs and subsequently classifying these into target task types. The resulting typology (see Table 9) is offered as a student-based, teacher-informed resource for the creation of MALL task-based lessons or curricula.

Chapelle (2005) would consider that many of the tasks in this table fit with the principles Doughty and Long (2003) outlined to guide decision-making in task design. The tasks are thus based on cognitive and interactionist theories of second language acquisition, which promote learning by doing and use rich, elaborate input. Several of the tasks listed above promote interaction and the negotiation of meaning, particularly around the content-based materials of an academic course. Several of the target tasks provide natural contexts for language development through interaction about content (see, for example, Tan \& Liu, 2004) with classmates, instructors, or others. More importantly, the list reflects the various task types that students requested because they need to carry these out whether they are in class or not. By incorporating these into the curriculum, the teacher is able to take advantage of what many students are doing in outside-of-class contexts. What our results further show is that teachers are looking at the use of mobile devices in ways that may reflect their more traditional understanding of purpose, such as 
tools for telephone communication and e-mail. The students, on the other hand, are envisioning more innovative uses of their mobile devices, such as using the video functions for practicing presentations. Exploring differences in the teachers' and students' views may help us identify areas of needed professional development.

\section{Table 9}

\section{Typology of Potential Task Types and Target Tasks}

\begin{tabular}{|c|c|c|}
\hline $\begin{array}{l}\text { Language } \\
\text { skill }\end{array}$ & Task types & Target tasks \\
\hline Reading & $\begin{array}{l}\text { Locating information } \\
\text { from English online } \\
\text { sources }\end{array}$ & $\begin{array}{l}\text { Define words using an online dictionary } \\
\text { Read online course materials for specific information } \\
\text { Search for specific content in an online newspaper } \\
\text { Search for specific content in a website } \\
\text { Search for specific content online } \\
\text { Find a content source to use in writing assignment }\end{array}$ \\
\hline \multirow[t]{2}{*}{$\begin{array}{l}\text { Listening/ } \\
\text { speaking }\end{array}$} & $\begin{array}{l}\text { Using the telephone for } \\
\text { voice calls }\end{array}$ & $\begin{array}{l}\text { Call friends } \\
\text { Call classmates and relay content from class } \\
\text { Call for reservation (e.g., hospital, restaurant) } \\
\text { Make an appointment } \\
\text { Call faculty to ask for information } \\
\text { Order from a restaurant } \\
\text { Summarize your thoughts orally for later transcribing } \\
\text { Record your voice to compare pronunciation }\end{array}$ \\
\hline & $\begin{array}{l}\text { Using a dictation/video } \\
\text { app }\end{array}$ & Create a video-recording of a short presentation \\
\hline \multirow[t]{2}{*}{ Listening } & $\begin{array}{l}\text { Gathering information } \\
\text { from English online } \\
\text { sources }\end{array}$ & $\begin{array}{l}\text { Listen to a lecture and text key info to classmate } \\
\text { Listen to the news and call classmate to talk } \\
\text { Listen to podcasts and text to/call classmate } \\
\text { Watch YouTube and text key info to classmate } \\
\text { Fill in graphics to take notes }\end{array}$ \\
\hline & $\begin{array}{l}\text { Taking notes from an } \\
\text { online source }\end{array}$ & Take notes without graphic assistance \\
\hline \multirow[t]{2}{*}{ Writing } & Sending e-mails & $\begin{array}{l}\text { Write formal e-mail (to faculty, etc.) } \\
\text { Write informal e-mail (to friends, etc.) } \\
\text { Chat (via SMS) with classmates about the course } \\
\text { Use online sources to outline a paper } \\
\text { Use app functions for remembering and note-taking } \\
\text { Take a picture and send it with an e-mail }\end{array}$ \\
\hline & $\begin{array}{l}\text { Posting written } \\
\text { contents online }\end{array}$ & $\begin{array}{l}\text { Post on social networking sites } \\
\text { Submit assignments on the course website } \\
\text { Reply to classmates' comments on the course } \\
\text { website }\end{array}$ \\
\hline
\end{tabular}

The teachers in our study were highly interested in meeting their students' wishes for using mobile technology despite being uncertain about how to implement it. This suggests that teachers may need a technology push in the form of professional development to build their confidence with mobile technology, so that they can attain the same levels of comfort and familiarity 
with mobile devices as their students. The findings from this study showed that the ESL teachers were more unfamiliar than their students with teaching and learning using mobile devices, although they were enthusiastic about attempting to bring their use into the classroom. The professional development that this study advocates does not necessarily need to focus on teaching teachers to use these tools; it instead needs to guide teachers to be more comfortable with MALL and to learn how mobile technology can be used as a teaching and learning tool both in and out of the classroom, and thus incorporate task-based mobile, technology-infused language teaching:

Concerned teachers are continually requesting more training and additional professional development about using technology. But ... there is a paradox, because to be the most successful at using technology in the classroom, teachers do not need to learn to use it themselves (although they can if they want to). What teachers do need to know is just how technology can and should be used by students to enhance their own learning. (Prensky, 2010, p. 3)

Language teachers are trained to understand what language learning is all about, but teacher training with and research into MALL has not been able to keep up with the speed of technological development (Ballance, 2013), and it is critical to ensure that teachers understand the pedagogical value of technology (de la Fuente, 2014), and what technology can and cannot accomplish (Levy, 2009). By asking students how they use their mobile devices, educators can focus on creating tasks that are useful for promoting language learning both in and outside the classroom.

\section{Conclusion}

Questions surrounding the use of technology in ESL teaching and learning have recently ranked among the most common research priorities (TESOL Research Agenda Task Force, 2014). One of the first questions posed in the 2014 TESOL research agenda document asked, "What uses do learners make of mobile-assisted language learning opportunities?" (p. 9), followed by "How can online communities best be used to support (1) language use and (2) the development of particular skills?" (p. 13). With pressing questions such as these, the current study sought to examine ESL students' and teachers' use of, their experience around, and their needs/desires regarding the use of mobile devices for teaching and learning contexts. In doing so, the study did not only confirm previous work regarding both the limitations and the cost of such tools as well as the potential for using these devices to carry out classroom-based learning tasks. It also illuminated the contrasts between ESL students, who generally felt comfortable and enthusiastic about MALL and used it outside the classroom, and ESL teachers, who were enthusiastic about MALL's potential in the classroom but much more unfamiliar with the tech- 
nology. It also highlighted a need to pay more attention to professional development so that teachers' understanding of and ability to work with MALL is enhanced. Moreover, the study offered the start of a foundational typology for the development of interaction-based teaching and learning tasks that aim to address the self-perceived language learning needs and desires of academic, college-aged ESL students, target tasks that were consistently acknowledged as being important in academic contexts by both ESL students and their teachers. Given the sheer volume of implementation studies to date, we are confident that future work on how to implement these ideas will be undertaken.

Many ESL students are already using mobile devices daily for a diverse variety of purposes, including language learning. It is now time to take advantage of these task types to meet the needs and wishes of the students themselves.

\section{Acknowledgements}

We would like to acknowledge the dedicated ESL students and teachers who agreed to participate in the study. Also, we would like to thank Dr. Gulbahar Beckett and Dr. Marian Rossiter, who offered valuable insights along the way, the anonymous TESL Canada reviewers, and the guest editor, Dr. William Dunn, for their careful and insightful feedback.

\section{The Authors}

Moonyoung Park is a PhD candidate in the Applied Linguistics and Technology program at Iowa State University. His areas of interest include task-based language assessment and teaching, and computer-assisted language learning. For his dissertation, he is currently researching task-based aviation English performance assessment in a virtual environment.

Tammy Slater is an Assistant Professor of Applied Linguistics/TESL at Iowa State University. Her research, which draws upon analytic methods from systemic functional linguistics, explores the development of academic language through content-based and project-based teaching and learning, particularly as these inform the field of education for English language learners.

\section{References}

Ballance, O. J. (2013). MALL: Somewhere between the tower, the field, the classroom and the market: A reply to Professor Stockwell's response. Language Learning \& Technology, 17(1), $37-46$.

Baron, N. S. (2008). Always on: Language in an online and mobile world. New York, NY: Oxford University Press.

Bax, S. (2000). Putting technology in its place. In C. Field (Ed.), Issues in modern foreign languages teaching (pp. 208-219). New York, NY: Routledge.

Bax, S. (2003). CALL: Past, present and future. System, 31(1), 13-28.

Bax, S. (2011). Normalisation revisited: The effective use of technology in language education. International Journal of Computer-Assisted Language Learning and Teaching, 1(2), 1-15.

Bibby, S. (2011). Do students wish to "go mobile"?: An investigation into student use of PCs and cell phones. International Journal of Computer-Assisted Language Learning and Teaching, 1(2), 43-54.

Burston, J. (2013). Mobile-assisted language learning: A selected annotated bibliography of implementation studies 1994-2012. Language Learning \& Technology, 17(3), 157-224.

Burston, J. (2014). MALL: The pedagogical challenges. Computer Assisted Language Learning, 27(4), 344-357. 
Chapelle, C. A. (2001). Computer applications in second language acquisition. Cambridge, UK: Cambridge University Press.

Chapelle, C. A. (2005). Interactionist SLA theory in CALL research. In J. L. Egbert \& G. M. Petrie (Eds.), CALL research perspectives (pp. 53-64). New York, NY: Routledge.

Chapelle, C. A. (2009). The relationship between second language acquisition theory and computer-assisted language learning. Modern Language Journal, 93(s1), 741-753.

Chinnery, G. M. (2006). Emerging technologies: Going to the MALL: Mobile assisted language learning. Language Learning \& Technology, 10(1), 9-16.

de la Fuente, M. J. (2014). Learners' attention to input during focus on form listening tasks: The role of mobile technology in the second language classroom. Computer Assisted Language Learning, 27(3), 261-276.

Doughty, C. (1987). Relating second-language acquisition theory to CALL research and application. In W. F. Smith (Ed.), Modern media in foreign language education: Theory and implementation (pp. 133-167). Lincolnwood, IL: National Textbook.

Doughty, C. J., \& Long, M. H. (2003). Optimal psycholinguistic environments for distance foreign language learning. Language Learning \& Technology, 7(3), 50-80.

Ellis, R. (2003). Task-based language learning and teaching. Oxford, UK: Oxford University Press.

Garrett, N. (1991). Technology in the service of language learning: Trends and issues. Modern Language Journal, 75(1), 74-100.

Garrett, N. (2009). Computer-assisted language learning trends and issues revisited: Integrating innovation. Modern Language Journal, 93(s1), 719-740.

Godwin-Jones, R. (2011). Emerging technologies: Mobile apps for language learning. Language Learning \& Technology, 15(2), 2-11.

Herrington, J., Herrington, A., Mantei, J., Olney, I., \& Ferry, B. (2009). Using mobile technologies to develop new ways of teaching and learning. In J. Herrington, A. Herrington, J. Mantei, I. Olney, \& B. Ferry (Eds.), New technologies, new pedagogies: Mobile learning in higher education (pp. 1-14). Wollongong, Australia: University of Wollongong.

Hutchinson, T., \& Waters, A. (1987). English for specific purposes. Cambridge, UK: Cambridge University Press.

Kiernan, P. J., \& Aizawa, K. (2004). Cell phones in task based learning: Are cell phones useful language learning tools? ReCALL, 16(1), 71-84.

Kim, D., Rueckert, D., Kim, D.-J., \& Seo, D. (2013). Students' perceptions and experiences of mobile learning. Language Learning \& Technology, 17(3), 52-73.

Kukulska-Hulme, A. (2010). Guest editorial: Mobile learning as a catalyst for change. Open Learning, 25(3), 181-185.

Kukulska-Hulme, A., \& Shield, L. (2007, September). An overview of mobile assisted language learning: Can mobile devices support collaborative practice in speaking and listening? Paper presented at EUROCALL 2007 Conference Virtual Strand.

Kukulska-Hulme, A., \& Shield, L. (2008). An overview of mobile assisted language learning: From content delivery to supported collaboration and interaction. ReCALL, 20(3), 271-289.

Lee, J. F. (2000). Tasks and communicating in language classrooms. New York, NY: McGraw-Hill.

Lee, H., \& Lee, J. H. (2013). Implementing glossing in mobile-assisted language learning environments: Directions and outlook. Language Learning \& Technology, 17(3), 6-22.

Levy, M. (2009). Technologies in use for second language learning. Modern Language Journal, 93(s1), 769-782.

Lin, H. (2014). Establishing an empirical link between computer-mediated communication (CMC) and SLA: A meta-analysis of the research. Language Learning \& Technology, 18(3), 120-147.

Long, M. H. (1985). A role for instruction in second language acquisition: Task-based language teaching. In K. Hyltenstam \& M. Pienemann (Eds.), Modeling and assessing second language acquisition (pp. 77-99). Clevedon, UK: Multilingual Matters.

Long, M. H. (2005). Methodological issues in learner needs analysis. In M. H. Long (Ed.), Second language needs analysis (pp. 1-76). Cambridge, UK: Cambridge University Press. 
Long, M. H., \& Norris, J. (2000). Task-based teaching and assessment. In M. Byram (Ed.), Routledge encyclopedia of language teaching and learning (pp. 597-603). London, UK: Routledge.

Munby, J. (1981). Communicative syllabus design. Cambridge, UK: Cambridge University Press.

Nah, K. C., White, P., \& Sussex, R. (2008). The potential of using a mobile phone to access the Internet for learning EFL listening skills within a Korean context. ReCALL, 20(3), 331-347.

Norris, J. M. (2009). Task-based teaching and testing. In M. H. Long \& C. Doughty (Eds.), Handbook of language teaching (pp. 578-594). Oxford, UK: Wiley-Blackwell.

Ogata, H., Hui, G. L., Yin, C., Ueda, T., Oishi, Y., \& Yano, Y. (2008). Supporting mobile language learning outside classrooms. International Journal of Mobile Learning and Organisation, 2(3), 271-282.

Park, Y. (2011). A pedagogical framework for mobile learning: Categorizing educational applications of mobile technologies into four types. International Review of Research in Open and Distance Learning, 12(2), 1-13.

Prensky, M. (2010). Teaching digital natives: Partnering for real learning. Thousand Oaks, CA: Corwin.

Richterich, R., \& Chancerel, J. L. (1980). Identifying the needs of adults learning a foreign language. Oxford, UK: Pergamon.

Shudong, W., \& Higgins, M. (2006). Limitations of mobile phone learning. JALT CALL Journal, 2(1), 3-14.

Skehan, P. (1998). A cognitive approach to language learning. Oxford, UK: Oxford University Press.

Stockwell, G. (2008). Investigating learner preparedness for and usage patterns of mobile learning. ReCALL, 20(3), 253-270.

Stockwell, G. (2010). Using mobile phones for vocabulary activities: Examining the effect of the platform. Language Learning \& Technology, 14(2), 95-110.

Tan, T. H., \& Liu, T. Y. (2004). The mobile-based interactive learning environment (MOBILE) and a case study for assisting elementary school English learning. Proceedings of the IEEE International Conference on Advanced Learning Technologies (pp. 530-534).

TESOL Research Agenda Task Force. (2014). TESOL International Association Research Agenda 2014. Retrieved from tesol-international-association-research-agenda-2014-2-2.pdf

Thornton, P., \& Houser, C. (2003). Using mobile web and video phones in English language teaching: Projects with Japanese college students. In B. Morrison, C. Green, \& G. Motteram (Eds.), Directions in CALL: Experience, experiments and evaluation (pp. 207-224). Hong Kong: English Language Centre, Hong Kong Polytechnic University.

van Ek, J. A. (1975). Systems development in adult language learning: The threshold level in a European unit/credit system for modern language learning by adults. Strasbourg, France: Council of Europe.

Warschauer, M. (2000, July). The death of cyberspace and the rebirth of CALL . Paper presented at the "CALL for the 21st Century" IATEFL and ESADE Conference, Barcelona, Spain.

Warschauer, M., \& Healey, D. (1998). Computers and language learning: An overview. Language Teaching, 31(2), 57-71.

Watanabe, Y. (2006). A needs analysis for a Japanese high school EFL general education curriculum. Second Language Studies, 25(1), 83-163.

Willis, D., \& Willis, J. (2007). Doing task-based teaching. Oxford, UK: Oxford University Press.

Yoshida, K., \& Naganuma, K. (2003). Eigo can-do anketo chousabunnseki houkokusho: Bassuibann [English can-do survey report: A summary]. Retrieved from http://benesse.jp/berd/center/ open/kokusai/report/2003/07/rep0716.html

Zhang, H., Song, W., \& Huang, R. (2014). Business English vocabulary learning with mobile phone: A Chinese students' perspective. International Journal of Computer-Assisted Language Learning and Teaching, 4(2), 46-63. 